\title{
Biological aspects of Aphis gossypii Glöver, 1877 (Hemiptera: Aphididae) on colored lint cotton cultivars
}

\author{
Aspectos biológicos de Aphis gossypii Glöver, 1877 (Hemiptera: Aphididae) \\ em cultivares de algodoeiro com fibra colorida
}

\author{
Lilian Roberta Batista Correa1*, Francisco Jorge Cividanes', Saulo Rene Damião Sala'
}

RESUMO: Este trabalho teve por objetivos estudar aspectos biológicos de Aphis gossypii em cultivares de algodoeiro de fibra colorida, construir tabelas de vida e avaliar a influência da densidade de tricomas e glândulas de gossipol das folhas das plantas na biologia do pulgão. Os ensaios foram conduzidos em câmara climatizada regulada a $25 \pm 2^{\circ} \mathrm{C}$, UR de $70 \pm 10 \%$ e fotofase de 12 horas, utilizando-se as seguintes cultivares: BRS Rubi, BRS Safira e BRS Verde. Ninfas recém-nascidas foram isoladas individualmente em placas de Petri contendo discos foliares de algodoeiro das cultivares sobre uma lâmina de ágar-água (1\%) de aproximadamente $5 \mathrm{~mm}$. A avaliaçáo da densidade de tricomas e de glândulas de gossipol das folhas das plantas foi realizada sob microscópio estereoscópico, delimitando-se uma área de $1 \mathrm{~cm}^{2}$ e, em seguida, realizando-se a contagem e identificaçáo dos mesmos nessa superfície. Os substratos alimentares avaliados influenciaram a fase ninfal de $A$. gossypii, sendo que a BRS Verde proporcionou menor tempo de duração e a BRS Safira, o maior período desta fase. A cultivar BRS Verde com a menor densidade de tricomas proporcionou elevada produçáo de ninfas e a maior taxa líquida de reproduçáo $\left(\mathrm{R}_{0}\right)$. Diante dos resultados, conclui-se que as cultivares de algodoeiro colorido influenciam o tempo de duraçáo da fase ninfal e adulta do pulgáo A. gossypii. A cultivar com elevada densidade de tricomas nas folhas (BRS Safira) afeta adversamente os padróes de fecundidade de A. gossypii.

PALAVRAS-CHAVE: pulgão do algodoeiro; fibra colorida; biologia; tricomas; gossipol.

\begin{abstract}
This paper outlines the results of a study into the biological aspects of Aphis gossypii Glöver on colored cotton cultivars through the construction of life tables. In addition, we evaluate the influence of density of gossypol glands and trichomes of leaves on the biology of the aphid. Tests were conducted in a climate chamber at $25 \pm 2^{\circ} \mathrm{C}$, with relative humidity $(\mathrm{RH})$ at $70 \pm 10 \%$, and a photophase of 12 hours, using the cultivars BRS Rubi, BRS Safira, and BRS Verde. Newly hatched nymphs were individually isolated in petri dishes containing leaf discs of cotton cultivars on a layer of water-agar (1\%) of approximately $5 \mathrm{~mm}$ thick. An evaluation of the trichomes and gossypol gland densities of the cotton leaf plants was performed under a stereomicroscope, delimited to an area of $1 \mathrm{~cm}^{2}$, and a count and identification of those on the surface was made. The feed substrates that were evaluated influenced the nymphal stage of A. gossypii. BRS Verde provided the shortest duration and BRS Safira was the longest during this phase. The cultivar BRS Verde, with the lowest density of trichomes, provided a large number of nymphs and led to a higher net reproductive rate $\left(\mathrm{R}_{0}\right)$. Given these results, conclusions can be drawn that the colored cotton cultivars influence the duration of nymphal and adult stages of $A$. gossypii. The cultivar with a high density of trichomes on leaves (BRS Safira) adversely affects the fertility parameters of $A$. gossypii.
\end{abstract}

KEYWORDS: cotton aphid; colored lint; biology; trichomes; gossypol. 


\section{INTRODUCTION}

The production of colored cotton fibers, both conventionally and organically grown, has been considered as a promising activity for producers and other participants in the production of cotton (BELTRÃo et al., 2004). The naturally colored cotton has no requirement to pass through the stages of preparation and dyeing, and as it has been grown in a system that fosters biological activity and encourages sustainability, it requires a management system different to that associated with the conventional production (SouzA, 2000). Thus, colored cotton is produced using agroecological and sustainable systems and through the management and protection of natural resources without using pesticides, genetically-modified organisms, chemical fertilizers, or other inputs harmful to human and animal health and to the environment (BELTRÃo et al., 2009).

Aphis gossypii (a tiny insect or greenfly, commonly known as the cotton aphid or melon aphid) is of significant economic importance in cotton production. These insects attack the plants early in their growing cycle, causing direct damage as a result of sap sucking (TAKAllOOZADEH, 2010) and they also have a considerably negative impact by transmitting the causative agents of several viruses to the plants (FonTes et al., 2006).

The development cycle and reproductive performance of $A$. gossypii and other aphid species may vary with the host plant, or even between different genotypes of the same plant species. In different cultivars of a species of plant, A. gossypii may make changes in its behavior, affecting the degree of susceptibility of the plant. Thus, when an inappropriate species of plant is used as food for these insects, it may have adverse effects on their biology, such as an irregular growth rate, deformation, reduced fertility, and diseases in the population. These adverse effects are the consequence of an inappropriate diet (deficient in some nutrients), or caused by the presence of toxic metabolites in these plants (Metcalf; Luckmann, 1994).

In this manner, morphological and chemical properties of plants can influence aspects of an insect's life cycle. For instance, the trichomes are appendages that can affect the activity of insects mechanically by pilosity, depending on their density, hardness, and the length and shape of the trichomes, just as chemicals can affect the insects through the release of allelochemicals (Oriani; Vendramim, 2010). The gossypol glands are involved in the defense of cotton cultivars, and their presence and density are negatively associated with the abundance and performance of herbivores, and the damage caused by them (Summy; King, 1992).

In the Brazilian scientific literature, there is little information on the biological aspects of the aphid A. gossypii in colored cotton cultivars. Therefore, it is emphasized that the Brazilian studies relate to determine the development time of different instars, as well as patterns of survival and fecundity, because they form the basis to establish pest control strategies and facilitate the adoption of integrated management programs (XIA et al., 1999). The construction of life tables is an important tool for the development of these strategies and, consequently, for improvement of management programs (RABB et al., 1984).

In this context, this study concentrated on the biological aspects of A. gossypii in colored cotton cultivars, as well as the construction of fertility and life expectancy tables, and on the evaluation of the influence of trichomes and gossypol glands present in the leaves of the plants on the aphid's biology.

\section{MATERIAL AND METHODS}

Experiments were carried out at the Laboratory of Insect Ecology and the experimental area of the Plant Protection Department of the Faculdade de Ciências Agrárias e Veterinárias/Universidade Estadual Paulista "Júlio de Mesquita Filho" (FCAV/UNESP). The following colored lint cotton cultivars were used in the tests: BRS Rubi, BRS Verde, and BRS Safira (Gossypium hirsutum latifolium Hutch Lr., herbaceous).

The tests were carried out in growth chambers set at $25 \pm 2^{\circ} \mathrm{C}$, relative humidity (RH) at $70 \pm 10 \%$, and a photophase of 12 hours. To obtain the nymphs used in the bioassays, ten adult females from the maintenance rearing group were isolated in one petri dish $(10 \mathrm{~cm}$ in diameter) containing a cotton leaf suspended in a solution of wateragar (1\%). Newly hatched nymphs were individually isolated from these dishes into petri dishes $(5 \mathrm{~cm}$ in diameter) containing leaf discs of the tested cotton cultivars $(4 \mathrm{~cm}$ in diameter) deposited on a layer of water-agar (1\%) of approximately $5 \mathrm{~mm}$ thick. The dishes were sealed with polyethylene film, and when necessary, the substrates of wateragar and leaf discs were renewed, transferring the insects to a new petri dish.

The experiment used a completely randomized design (CRD), with 50 replicates for the treatment. Each replicate consisted of one individual of $A$. gossypii maintained on the leaves within the petri dishes, using the three-colored cotton cultivars, namely, BRS Rubi, BRS Safira, and BRS Verde. Daily observations were made under a stereoscopic microscope, evaluating at the nymphal phase, the number and duration of each instar, the total duration of the phase, and survival in each of these stages. In the adult phase of $A$. gossypii, the longevity and daily and total capacity in terms of the production of nymphs, was determined.

Data were collected for the duration of instars of A. gossypii at the nymphal stage and during its adult phase life cycle. Daily and total nymph production and 
nymphal instars' survival rates were submitted for analysis of variance (ANOVA), and means were compared using the Tukey test at $5 \%$ probability. The life tables of the aphid were built according to Silveira Neto et al. (1976) and Michelotto et al. (2003).

To evaluate the density of gossypol glands and the trichomes present below the surface of the leaves of colored cotton cultivars used in biological assays, 25 leaves from the middle part of the plants of each cultivar were randomly selected. Sмiтн (1964) proposed that the counting of leaf trichomes should be performed on leaves located in the midline to the top of the plants for the characterization of cotton genotypes.

Under a stereomicroscope, an area of $1 \mathrm{~cm}^{2}$ was delimited on the leaves, and a count and identification of trichomes and gossypol glands on this surface were made. The trichomes were separated into morphologically simple, stellate, and forked, according to the classification system proposed by BONDADA; OosTerhuis (2000). The data obtained were subjected to analysis of variance (ANOVA) and means were compared using the Tukey test at $5 \%$ probability.

\section{RESULTS AND DISCUSSION}

The nymphs of $A$. gossypii presented four instars in all cultivars (Table 1). These results are similar to those obtained by other researchers who have studied the biology of this aphid in several cotton cultivars under different environmental conditions (Vendramim; Nakano 1981; Kersting et al., 1999; Michelotto et al., 2003; Pessoa et al., 2004), in chrysanthemum under different constant temperatures (Soglia et al., 2002; 2003), and in Cucurbitaceae plants (SATAR et al., 2005; Leite et al., 2008).

The feed substrates that were evaluated showed no influence on the duration of the instars of $A$. gossypii (Table 1). Conversely, the nymph and adult stages of the aphid were affected, which were found to depend on the substrates (Table 2). A shorter duration of the nymphal phase occurred when $A$. gossypii was reared on the cultivar BRS Verde, while the opposite was found when BRS Safira served as a feed substrate. The value obtained for BRS Safira (5.53 days) and BRS Rubi (5.29 days) differed from the results obtained by Pessoa et al. (2004), who found that values ranged from

Table 1. Mean \pm standard error values for different instars of Aphis gossypii on the basis of colored cotton cultivars ( $25 \pm 1{ }^{\circ} \mathrm{C}, 70$ $\pm 10 \%$ relative humidity, and 12 -hours photophase).

\begin{tabular}{|c|c|c|c|c|}
\hline \multirow{2}{*}{ Cultivars } & \multicolumn{4}{|c|}{ Instars (days) } \\
\hline & First & Second & Third & Fourth \\
\hline \multirow{2}{*}{ BRS Rubi } & $1.82 \pm 0.07$ & $1.18 \pm 0.06$ & $1.12 \pm 0.05$ & $1.18 \pm 0.06$ \\
\hline & $(n=50)$ & $(n=49)$ & $(n=49)$ & $(n=49)$ \\
\hline \multirow{2}{*}{ BRS Safira } & $1.84 \pm 0.05$ & $1.22 \pm 0.06$ & $1.16 \pm 0.05$ & $1.31 \pm 0.07$ \\
\hline & $(n=50)$ & $(n=49)$ & $(n=49)$ & $(n=49)$ \\
\hline \multirow{2}{*}{ BRS Verde } & $1.78 \pm 0.06$ & $1.16 \pm 0.05$ & $1.10 \pm 0.04$ & $1.17 \pm 0.05$ \\
\hline & $(n=50)$ & $(n=50)$ & $(n=49)$ & $(n=48)$ \\
\hline $\mathrm{F}$ & 0.26 & 0.34 & 0.42 & 1.65 \\
\hline p-value & 0.7747 & 0.7143 & 0.6599 & 0.1952 \\
\hline
\end{tabular}

Table 2. Mean \pm standard error values for life stages and life cycle of Aphis gossypii on the basis of colored cotton cultivars ( $25 \pm$ $1{ }^{\circ} \mathrm{C}, 70 \pm 10 \%$ relative humidity, and 12 -hours photophase).

\begin{tabular}{|c|c|c|c|}
\hline \multirow[b]{2}{*}{ Cultivars } & \multicolumn{3}{|c|}{ Stages/cycle (days) } \\
\hline & Nymphal stage & Adult stage & $\begin{array}{c}\text { Life cycle } \\
\text { (nymph - adult) }\end{array}$ \\
\hline \multirow{2}{*}{ BRS Rubi } & $5.29 \pm 0.08^{\mathrm{ab}}$ & $21.12 \pm 0.69^{b}$ & $26.41 \pm 0.68^{b}$ \\
\hline & $(n=49)$ & $(n=49)$ & $(n=49)$ \\
\hline \multirow{2}{*}{ BRS Safira } & $5.53 \pm 0.08^{a}$ & $23.88 \pm 0.69^{a}$ & $29.41 \pm 0.71^{\mathrm{a}}$ \\
\hline & $(n=49)$ & $(n=49)$ & $(n=49)$ \\
\hline \multirow{2}{*}{ BRS Verde } & $5.23 \pm 0.06^{b}$ & $23.48 \pm 0.69^{a}$ & $28.71 \pm 0.69^{\mathrm{ab}}$ \\
\hline & $(n=48)$ & $(n=48)$ & $(n=48)$ \\
\hline $\mathrm{F}$ & 4.38 & 4.66 & 5.05 \\
\hline $\mathrm{p}$-value & 0.0144 & 0.0111 & 0.0077 \\
\hline
\end{tabular}

Means followed by the same letter in column do not differ from each other by Tukey test at $5 \%$ probability. 
4.94 days to 5.23 days in four different cotton cultivars. Similarly, Funichello et al. (2009) obtained 5.06 days and 5.16 days for $\mathrm{NuOpal}^{\circledR}$ (GMO) and DeltaOpal ${ }^{\circledR}$ (white lint) cultivars, respectively.

On the feed substrate of BRS Rubi, A. gossypii presented the shortest duration of the adult phase (Table 2). The value of the duration of the adult phase found for this substrate is similar to that observed in cotton cultivar $\mathrm{NuOpal}^{\circledR}$ (21.83 days) (Funichello et al., 2009). The life cycle of this aphid had the longest period when reared on BRS Safira and the shortest on BRS Rubi (Table 2).

In all the cultivars studied, the average pre-reproductive period of A. gossypii was less than 24 hours. The shortest reproductive period occurred when the aphid was reared on BRS Rubi (Table 3). On the other hand, for the duration of the post-reproductive period of the aphid reared on the tested cultivars, no significant differences $(F=1.65$ and $\mathrm{p}=0.1790$ ) were found.

The variety of cotton, BRS Verde, enabled $A$. gossypii to produce a total number of nymphs significantly higher than was the case with the other cultivars, while BRS Rubi adversely affected the reproductive capacity of aphids as this cultivar produced the lowest number of nymphs. Nonetheless, the daily production of nymphs was not affected by the foods that were offered to the aphids (Table 3). However, the daily production of nymphs observed in the cultivars was in excess of that found by Kersting et al. (1999) (2.3 nymphs/ day) and PessoA et al. (2004) (3.0 nymphs/day), when they studied the biology of $A$. gossypii on cotton cultivars on Çukurova (Turkey) and IPEACO-SL (Brazil), respectively.

No adverse effect was observed on cultivars of colored cotton on the survival of different instars, and the nymphal stage of $A$. gossypii, verifying values between $96 \%$ and $100 \%$ (Table 4). A similar result for this biological parameter was obtained by PEsson et al. (2004), who studied this aphid in several cotton cultivars, showing survival values greater than $90 \%$. On the other hand, Du et al. (2004) observed survival values of less than $55 \%$ in commercial white lint cultivars of cotton.

Life expectancy $\left(e_{x}\right)$ was found to be high in the three cotton cultivars that were tested, reaching values of 25.59, 28.40, and 27.22 days for aphids reared on BRS Rubi, BRS Safira, and BRS Verde, respectively. Then a decrease was followed in the $e_{x}$ values, until the end of the evaluation period (Figure 1). Observing these results, initially BRS Rubi led to the lowest life expectancy $\left(\mathrm{e}_{\mathrm{x}}\right)$. Conversely, Miснецотто et al. (2004) observed lower initial values for $\mathrm{e}_{\mathrm{x}}$, ranging from 15 days to 23 days, for this same aphid species reared on weeds.

The highest mortality rate $\left(\mathrm{d}_{\mathrm{x}}\right)$ of $A$. gossypii reared on the cultivar BRS Rubi, occurred on the $28^{\text {th }}$ and $30^{\text {th }}$ days, giving a probability of death $\left(100 \mathrm{q}_{\mathrm{x}}\right)$ of $34.78 \%$ and $88.89 \%$, respectively. The highest mortality rate for BRS Safira and BRS Verde occurred on the $28^{\text {th }}$ day $(38.71 \%$ and $32.14 \%$, respectively). It is worth observing that in these periods, the aphids were already in adulthood, confirming the low

Table 3. Reproductive period \pm standard error and nymphs production \pm standard error of Aphis gossypii on the basis of colored cotton cultivars $\left(25 \pm 1^{\circ} \mathrm{C}, 70 \pm 10 \%\right.$ relative humidity, and 12 -hours photophase).

\begin{tabular}{|c|c|c|c|}
\hline \multirow{2}{*}{ Cultivars } & \multirow{2}{*}{ Reproductive period (days) } & \multicolumn{2}{|c|}{ Production of nymphs/females } \\
\hline & & Total & Daily \\
\hline \multirow[t]{2}{*}{ BRS Rubi } & $10.51 \pm 0.37^{c}$ & $55.76 \pm 1.30^{c}$ & $5.10 \pm 0.14$ \\
\hline & $(n=49)$ & $(n=49)$ & $(n=49)$ \\
\hline \multirow[t]{2}{*}{ BRS Safira } & $12.90 \pm 0.45^{b}$ & $60.98 \pm 1.30^{b}$ & $4.76 \pm 0.11$ \\
\hline & $(n=49)$ & $(n=49)$ & $(n=49)$ \\
\hline \multirow[t]{2}{*}{ BRS Verde } & $14.64 \pm 0.57^{\mathrm{a}}$ & $69.19 \pm 1.70^{a}$ & $4.90 \pm 0.16$ \\
\hline & $(n=48)$ & $(n=48)$ & $(n=48)$ \\
\hline $\mathrm{F}$ & 19.31 & 21.06 & 1.42 \\
\hline $\mathrm{p}$-value & $<0.001$ & $<0.001$ & 0.2453 \\
\hline
\end{tabular}

Means followed by the same letter in column do not differ from each other by Tukey test at $5 \%$ probability.

Table 4. Survival (\%) \pm standard error for instars and nymphal stage of Aphis gossypii on the basis of colored cotton cultivars ( $25 \pm 1^{\circ} \mathrm{C}, 70 \pm 10 \% \mathrm{RH}, 12$ hours photophase) $(\mathrm{n}=50)$.

\begin{tabular}{|c|c|c|c|c|c|}
\hline \multirow{2}{*}{ Cultivars } & \multicolumn{4}{|c|}{ Ínstars } & \multirow{2}{*}{ Nymphal stage } \\
\hline & First & Second & Third & Fourth & \\
\hline BRS Rubi & $100.0 \pm 0.0$ & $98.0 \pm 2.0$ & $100.0 \pm 0.0$ & $100.0 \pm 0.0$ & $98.0 \pm 2.0$ \\
\hline BRS Safira & $100.0 \pm 0.0$ & $98.0 \pm 2.0$ & $100.0 \pm 0.0$ & $100.0 \pm 0.0$ & $98.0 \pm 2.0$ \\
\hline BRS Verde & $100.0 \pm 0.0$ & $100.0 \pm 0.0$ & $98.0 \pm 2.0$ & $98.0 \pm 2.0$ & $96.0 \pm 2.67$ \\
\hline $\mathrm{F}$ & 1.00 & 0.33 & 1.00 & 1.00 & 0.24 \\
\hline $\mathrm{p}$-value & 0.4041 & 0.8014 & 0.4041 & 0.4041 & 0.8680 \\
\hline
\end{tabular}



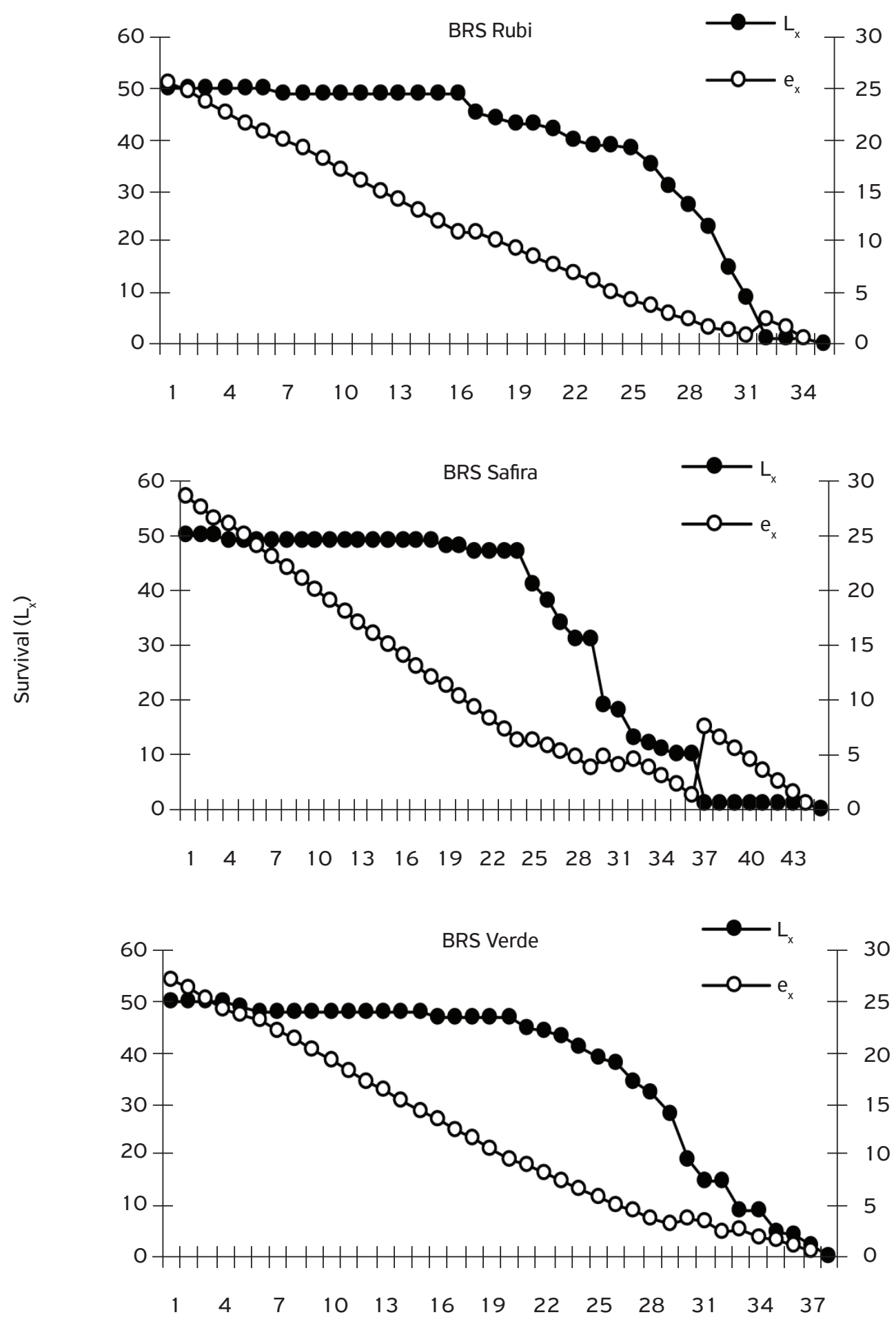

(days)

Figure 1. Survival $\left(L_{x}\right)$ and life expectancy $\left(e_{x}\right)$ of Aphis gossypii on the basis of colored cotton cultivars $\left(25 \pm 1^{\circ} \mathrm{C}, 70 \pm 10 \%\right.$ relative humidity, and 12-hours photophase).

mortality observed for nymphal instars of the aphid on these colored cotton cultivars (Table 4).

The critical period for an increased tendency of population growth of an insect species occurs between the intersection of the curves of fecundity $\left(m_{x}\right)$ and survival rate $\left(l_{x}\right)$ until the peak of reproduction (Mello et al., 1980). The reproductive peak, i.e., the highest values of $\mathrm{m}_{\mathrm{x}}$ (average number of nymphs/female) occurred on the $9^{\text {th }}$ day for BRS Safira and BRS Verde and on the $10^{\text {th }}$ day for BRS Rubi. The survival rate $\left(1_{x}\right)$ was initially high, and remained practically 


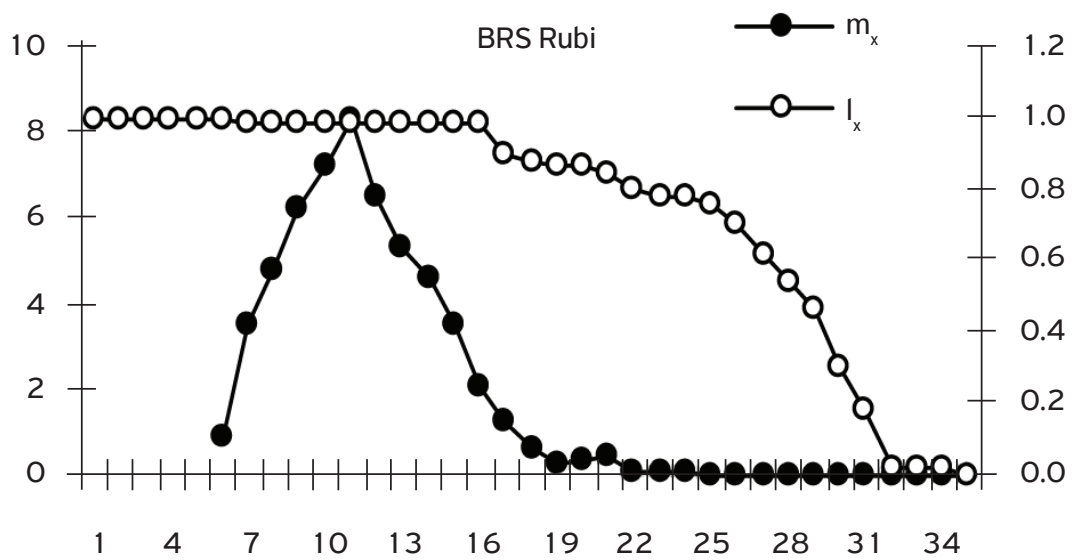

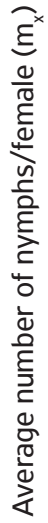
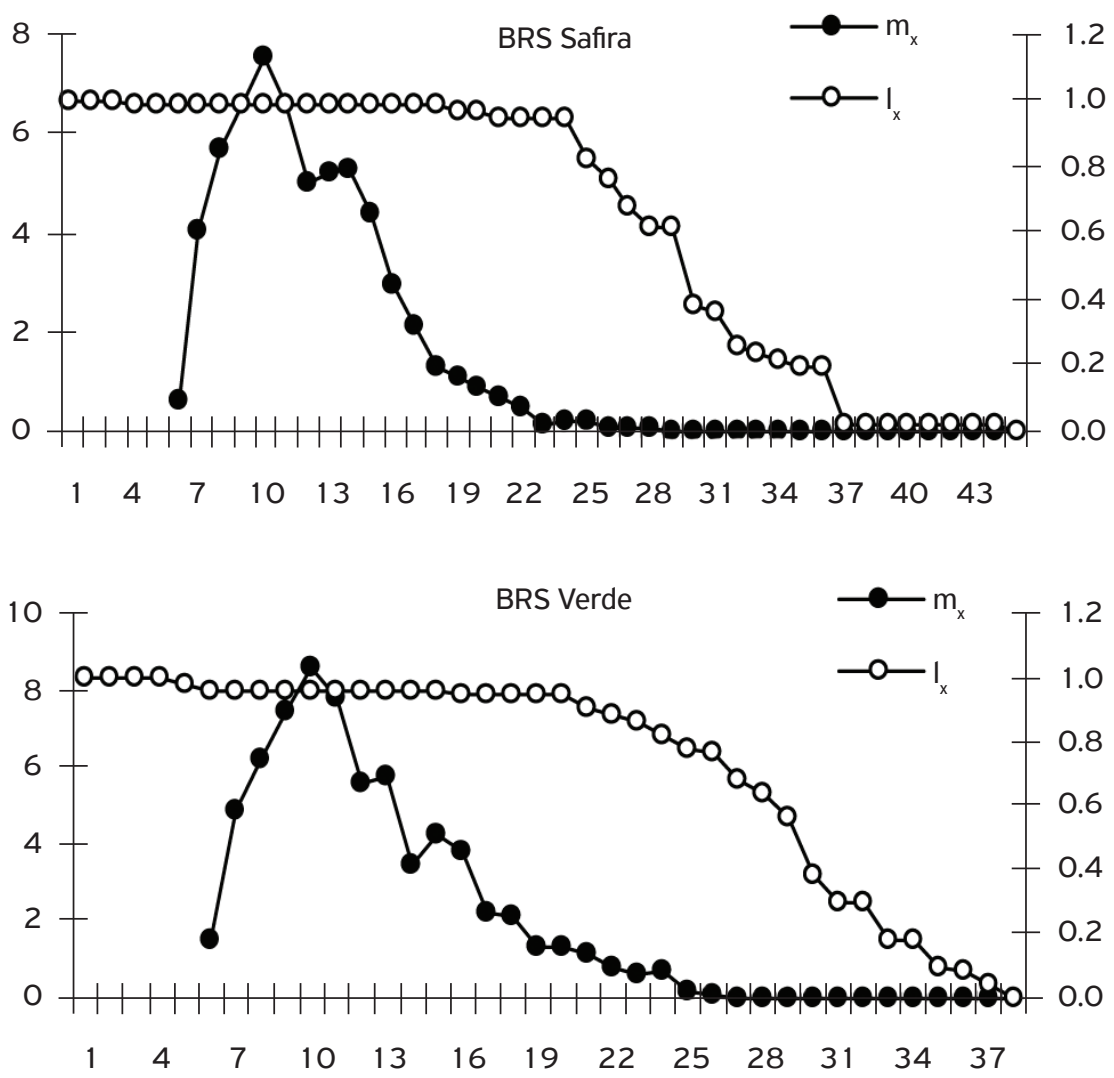

(days)

Figure 2. Average number of nymphs/female $\left(m_{x}\right)$ and survival rate $\left(I_{x}\right)$ of Aphis gossypii on the basis of colored cotton cultivars ( $25 \pm 1{ }^{\circ} \mathrm{C}, 70 \pm 10 \%$ relative humidity, 12 -hours photophase).

stable with small variations until the $15^{\text {th }}$ (BRS Rubi), $19^{\text {th }}$ (BRS Verde), and $23^{\text {rd }}$ days (BRS Safira). Thereafter, it fell down sharply until the end of the evaluations (Figure 2).

Considering the parameters of the life-fertility tables, the net reproductive rate $\left(\mathrm{R}_{0}\right)$ is an estimation of the expected number of offspring per female over a generation (Silveira Neto et al., 1976). In this study, $A$. gossypii showed an increased value of $\mathrm{R}_{0}$ on the cultivar BRS Verde, and a lower value on the cultivar BRS Rubi
(Table 5). It is worth observing that the values of $\mathrm{R}_{0}$ on the tested cultivars were higher than those observed by Kersting et al. (1999) for this aphid reared on cotton cultivar Çukorova (44.7 nymphs/female/generation). However, Michelotтo et al. (2003) found a higher value of $\mathrm{R}_{0}$ for $A$. gossypii reared on cotton cultivar DeltaOpal ${ }^{\circledast}$ (82.08 nymphs/female/generation).

The time interval between each generation $(\mathrm{T})$ and the time required for the population to double (TD) in this 
study was greater in the case of BRS Verde and BRS Safira (Table 5). Michelotтo et al. (2003) found similar values to those obtained on BRS Rubi, for T (10.45 days) and TD (1.81 days), for $A$. gossypii reared on cotton cultivar CNPA ITA 90, whilst Kersting et al. (1999) found a higher value of the parameter $\mathrm{T}$ ( 15.1 days on cotton cultivar Çukorova) compared to those observed on colored cotton cultivars.

The values of the innate ability to increase in numbers $\left(\mathrm{r}_{\mathrm{m}}\right)$ and of the finite rate of increase $(\lambda)$ were lower when $A$. gossypii was reared on BRS Safira and greater when reared on BRS Rubi (Table 5). However, the results obtained for these parameters on BRS Rubi were lower than those obtained by Michelotto et al. (2003) $\left(\mathrm{r}_{\mathrm{m}}=0.390\right.$ and $\lambda=1.477$ nymphs/female/day) for this aphid reared on DeltaOpal $^{\circledast}$ cultivar.

BRS Safira presented the largest number of trichomes and the smallest coverage of gossypol glands, with regards to the morphological characteristics of the cotton leaves that were evaluated (Table 6). Three types of trichomes were observed on the lower surfaces of leaves of colored cotton, i.e., simple, stellate, and forked.

It is notable that the cultivar with the highest density of trichomes (BRS Safira) caused a prolongation of the nymphal stage of the aphid. Thus, the high density of trichomes formed a mechanical barrier, hindering access to food by the nymphs because of their small size (SogLia et al., 2002). According to LaRA (1991), the morphological characteristics of plants can change the behavior of insects, and also interfere with their biology, reducing their adaptive capacity and giving protection to plants.

Similarly, the density of leaf trichomes of colored cotton cultivars affected the fertility patterns of $A$. gossypii. It was observed that BRS Verde, with the lowest density of trichomes (Table 6), featured a high production of nymphs and an increased net reproductive rate $\left(\mathrm{R}_{0}\right)$ (Table 5). SogLiA et al. (2003) also observed that in chrysanthemum cultivars, with a higher density of trichomes, A. gossypii showed a lower fecundity rate. The reproductive potential of aphids can be affected by several factors, among which include the quality of the host plant and the occurrence of natural resistance in the plants (KocoureK et al., 1994).

Furthermore, the gossypol glands present on cotton leaves showed that BRS Rubi, with the highest density of such glands, (Table 6) led to the lowest adult longevity and lowest fertility patterns (small production of nymphs and low value for $\mathrm{R}_{0}$ ) (Table 5). Du et al. (2004), studying the biology of $A$. gossypii, also observed this effect in cotton cultivars with a higher density of gossypol glands.

It is emphasized that the information on the development and fecundity of aphids from particular hosts and regions should be used with caution, if applied to different cultures and regions, from those in which the study took place (Akey; Butler, 1989). The existence of different breeds and host incompatibility is a common phenomenon in A. gossypii, making it important to study the interactions with aphid host plants in different regions (SATAR et al., 1999).

Conclusions can be drawn from the results obtained that the colored cotton cultivars influence the duration of the nymphal and adult phases of $A$. gossypii, and its survival is not affected. This data showed that BRS Verde cultivar with a low density of trichomes on the leaves, promotes the highest degree of fecundity on the part of $A$. gossypii. BRS Rubi cultivar with a high density of gossypol glands has an adverse effect on the fecundity and longevity of adults of $A$. gossypii.

\section{ACKNOWLEDGMENTS}

We thank the Fundação de Amparo a Pesquisa do Estado de São Paulo (FAPESP) for granting a PhD scholarship to the first author and EMBRAPA Algodão (Campina Grande $\mathrm{PB}$, Brazil) for providing seeds of colored cotton.

Table 6. Mean number of trichomes $/ \mathrm{cm}^{2}$ and gossypol glands $/ \mathrm{cm}^{2}$ ( \pm standard error) present underneath leaves of colored cotton cultivars $(n=25)$.

\begin{tabular}{lcc} 
Cultivars & Trichomes & Gossypol glands \\
\hline BRS Rubi & $55.5 \pm 5.93^{\mathrm{b}}$ & $90.5 \pm 3.69^{\mathrm{a}}$ \\
\hline BRS Safira & $109.4 \pm 6.99^{\mathrm{a}}$ & $58.6 \pm 3.25^{\mathrm{b}}$ \\
\hline BRS Verde & $25.08 \pm 1.49^{\mathrm{c}}$ & $78.5 \pm 2.47^{\mathrm{a}}$ \\
\hline F & 77.42 & 26.38 \\
\hline p-value & $<0.001$ & $<0.001$
\end{tabular}

Means followed by the same letter in column do not differ from each other according to the Tukey test at 5\% probability.

Table 5. Life-fertility table parameters of Aphis gossypii on the basis of colored cotton cultivars $\left(25 \pm 1^{\circ} \mathrm{C}, 70 \pm 10 \%\right.$ relative humidity, 12-hours photophase).

\begin{tabular}{|c|c|c|c|c|c|}
\hline \multirow{2}{*}{ Cultivars } & $\mathbf{T}$ & $\mathbf{R}_{0}$ & $r_{m}$ & $\lambda$ & TD \\
\hline & (days) & (nymphs/females/generation) & - & (nymphs/female/day) & (days) \\
\hline BRS Rubi & 10.451 & 54.641 & 0.383 & 1.467 & 1.810 \\
\hline BRS Safira & 11.079 & 59.760 & 0.369 & 1.446 & 1.878 \\
\hline BRS Verde & 11.166 & 66.420 & 0.376 & 1.456 & 1.843 \\
\hline
\end{tabular}

T: time interval between each generation; $R_{0}$ : net reproduction rate; $r_{m}$ : innate capacity for increasing in number; $\lambda$ : finite rate of increase; TD: time required for population to double. 


\section{REFERENCES}

AKEY, D.H.; BUTLER JUNIOR, G.G. Development rates and fecundity of Aphis gossypii on seedlings of Gossypium hirsutum. Southwestern Entomologist, Texas, v. 14, p.295-299, 1989.

BELTRÃO, N.E.M.; MENDES, M.C.; CARDOSO, G.D.; VIEIRA, C.M.; CHITARRA, L.G.; SCHONS, A.U. Populações de plantas e época de plantio na cultura do algodão colorido BRS 2000 marrom no estado do Mato Grosso, município do Colíder. Campina Grande: MAPA, 2004. 4p. (Comunicado técnico 214).

BELTRÃO, N.E.M.; SILVA, C.A.D.; SUINAGA, F.A.; ARRIEL, N.H.C.; RAMALHO, F. S. Algodão agroecológico: opção de agronegócio para o Semi-árido do Brasil. Campina Grande: Embrapa Algodão, 2009. 66p. (Embrapa Algodão. Documentos, 222).

BONDADA, B.R.; OOSTERHUIS, D.M. Comparative epidermal ultrastructure of cotton (Gossypium hirsutum L.) leaf, bract and capsule wall. Annals of Botany, v.86, n.6, p. 1 143-1 152, 2000.

DU, L.; GE, F.; ZHU, S.; PARAJULEE, M.N. Effect of cotton cultivar on development and reproduction of Aphis gossypii (Hemiptera: Aphididae) and its predator Propylaea japonica (Coleoptera: Coccinellidae). Journal of Economic Entomology, v.97, n.4, p.1278-1283, 2004.

FONTES, E.M.G.; RAMALHO, F.S.; UNDERWOOD, E.; BARROSO P.A.V.; SIMON, M.F.; SUJII, E.R.; PIRES, C.S.S.; BELTRÃO, N.; LUCENA, W.A.; FREIRE, E.C. The cotton agricultural context in Brazil. In: HILBECK, A.; ANDOW, D.A.; FONTES, E.M.G. (Ed.). Environmental risk assessment of genetically modified organisms: methodologies for assessing Bt cotton in Brazil. Wallingford: CABI Publishing, 2006. p.21-66.

FUNICHELLO, M.; COSTA, L.L.; PESSOA, R.; RIBEIRO, A.A.; BUSOLI, A. C. Biologia comparada de Aphis gossypii Glöver, 1877 (Hemiptera: Aphididae) nas cultivares de algodoeiro NuOpal (Bollgard I) e DeltaOpal. In: Congresso Brasileiro Do Algodão, 7., 2009, Foz do Iguaçu. Sustentabilidade da Cotonicultura Brasileira e Expansão dos Mercados. Anais. Campina Grande: Embrapa Algodão, 2009. p.540-547.

KERSTING, U.; SATAR, S.; UYGUN, N. Effect of temperature on development rate and fecundity of apterous Aphis gossypii Glöver, 1877 (Hemiptera: Aphididae) reared on Gossypium hirsutum L. Journal of Applied Entomology, Dordrecht, v.123, n. 1, p.23-27, 1999.

KOCOUREK, F.; HAVELKA, J.; BERANKOVA, J.; JAROSIK, V. Effect of temperature on development rate and intrinsic rate of increase of Aphis gossypii reared on greenhouse cucumbers. Entomologia Experimentalis et Applicata, Dordrech, v.71, n.1, p.59-64, 1994.

LARA, F.M. Princípios de Resistência de Plantas a Insetos. 2ed. São Paulo: Ícone, 1991. 207p.

LEITE, M.V.; SANTOS, T.M.; SOUZA, B.; CALIXTO, A. M.; CARVALHO, C.F. Biologia de Aphis gossypii Glöver, 1877 (Hemiptera: Aphididae) em abobrinha cultivar Caserta
(Cucurbita pepo L.) em diferentes temperaturas. Ciência $e$ Agrotecnologia, Brazil, v.32, n.5, p.1394-1401, 2008.

MELLO, A.M.L.T.; SILVEIRA NETO, S.; PARRA, J.R.P. Tabela de fertilidade de vida de Gryllus assimilis (Fabricius, 1775) (Orthoptera, Gryllidae) em laboratório. Anais da Sociedade Entomológica do Brasil, Brazil, v.9, p.133-140, 1980.

METCALF, R.L.; LUCKMANN, W.H. Introduction to Insect Pest Management. New York: John Wiley \& Sons, 1994. 650p.

MICHELOTTO, M.D.; SILVA, M.D.; BUSOLI, A.C. Tabela de esperança de vida e fertilidade para Aphis gossypii Glöver, 1877 (Hemiptera: Aphididae) em três cultivares de algodoeiro. Boletin Sanidad Vegetal Plagas, Madrid, v.29, n.3, p.331-337, 2003.

MICHELOTTO, M.D.; SILVA, M.D.; BUSOLI, A.C. Tabela de esperança de vida e fertilidade para Aphis gossypii Glöver, 1877 (Hemiptera: Aphididae) em três espécies de plantas daninhas. Boletin Sanidad Vegetal Plagas, Madrid, v.30, p.211-217, 2004

ORIANI, M.A.G.; VENDRAMIM, J.D. Influence of trichomes on attractiveness and ovipositional preference of Bemisia tabaci (Genn.) B Biotype (Hemiptera: Aleyrodidae) on tomato genotypes. Neotropical Entomology, Londrina, v.39, n.6, p.1002-1007, 2010.

PESSOA, L.G.A.; SOUZA, B.; CARVALHO, C.F.; SILVA, M.G. Aspectos da biologia de Aphis gossypii Glöver, 1877 (Hemiptera: Aphididae) em quatro cultivares de algodoeiro, em laboratório. Ciência $e$ Agrotecnologia, Lavras, v.28, n.6, p.1235-1239, 2004.

RABB, R.L.; DEFOLIARI, G.R.; KENNEDY, G.G. An ecological approach to managing insect populations. In: HUFFAKER, C.B.; RABB, R.L. (Ed.). Ecological Entomology. New York: John Wiley, 1984. p.697-728.

SATAR, S.; KERSTING, U.; UYGUN, N. Development and fecundity of Aphis gossypii Glöver (Homoptera: Aphididae) on three Malvaceae hosts. Turkish Journal of Agriculture and Forestry, Ankara, v.23, n.6, p.367-643, 1999.

Effect of temperature on development and fecundity of Aphis gossypii Glöver (Homoptera: Aphididae) on cucumber. Journal of Pest Science, Heidelberg, v.78, n.3, p.133-137, 2005.

SILVEIRA NETO, S; NAKANO, O.; BARBIN, D.; VILLA NOVA, N.A. Manual de ecologia dos insetos. São Paulo: Agronômica Ceres, 1976. $419 \mathrm{p}$.

SMITH, A.L. Leaf trichomes of Upland cotton varieties. Crop Science, v.4, p.348-349, 1964.

SOGLIA, M.C.M., BUENO, V.H.P.; SAMPAIO, M.V. Desenvolvimento e sobrevivência de Aphis gossypii Glöver, 1877 (Hemiptera: Aphididae) em diferentes temperaturas e cultivares comerciais de crisântemo. Neotropical Entomology, Londrina, v.31, n.2, p.211-216, 2002 . 
SOGLIA, M.C.M., BUENO, V.H.P.; RODRIGUES, S.M.M.; SAMPAIO, M.V. Fecundidade e longevidade de Aphis gossypii Glöver, 1877 (Hemiptera: Aphididae) em diferentes temperaturas e cultivares comerciais de crisântemo (Dendrathema grandiflora Tzvelev). Revista Brasileira de Entomologia, Curitiba, v.47, n.1, p.49-54, 2003.

SOUZA, M.C.M. Produção e algodão colorido: possibilidades e limitações. Informações Econômicas, São Paulo, v.30, n.6, p.91-98, 2000.

SUMMY, K.R.; KING, E.G. Cultural control of cotton insect pests in the United States. Crop Protection, Oxford, v.1 1, p.307-319, 1992.
TAKALLOOZADEH, H.M. Effects of host plants and various temperatures on population growth parameters of Aphis gossypii Glöver (Homopetra: Aphididae). Journal of Scientific Research, Bangladesh, v.6, n.1, p.25-30, 2010.

VENDRAMIM, J.D.; NAKANO, O. Aspectos biológicos de Aphis gossypii Glöver, 1877 (Hemiptera: Aphididae) em algodoeiro. Anais da Sociedade Entomológica do Brasil, Londrina, v.10, n.2, p. $163-173,1981$.

XIA, J.Y.; WERF, W.; RABBINGE, R. Influence of temperature on bionomics of cotton aphid, Aphis gossypii, on cotton. Entomologia Experimentalis et Applicata, Amsterdam, v.90, p.25-35, 1999. 